\title{
European Union Monitoring Mission in Georgia (2008-2019): contribution to stability or part of a problem?
}

\section{Přispěla Monitorovací mise Evropské unie (2008-2019) ke stabilitě v regionu nebo se naopak stala součástí konfliktu?}

\section{Tereza Smejkalová}

Abstract: The EU Monitoring Mission (EUMM) is the only international monitoring presence operating in the region with the consent of the Russian Federation. However, almost 11 years in the area did not bring the desired result. The Russian Federation has strengthened its position in Abkhazia and South Ossetia with more than 20,000 troops on the ground, hardened the border and even prevented the schools from teaching children in Georgian. Following the assessment on the basis of three criteria (stabilization, normalization and confidence building), the EUMM attempts to increase the confidence building, to mediate among the actors in order to achieve a normal and a stable environment. But on the other hand, EUMM enables also the Russian federation to officialise its presence and its troops in the breakaway regions.

Abstrakt: $\quad$ Evropská unie se již více než 10 let zapojuje do řešení konfliktu v Gruzii. Jedná se o jedinou mezinárodní monitorovací přítomnost (Monitorovací mise EU), která v oblasti operuje se souhlasem Ruské federace. Téměř 11 let v oblasti však nepřineslo kýžený výsledek. Konflikt se sice stabilizoval, ale zamrzl na mrtvém bodě. Ruská federace upevnila svou pozici v Abcházii a Jižní Osetii s více než 20.000 vojáky, dosáhla hraničního vymezení a dokonce zamezila výuce dětí v gruzínštině. Na základě hodnocení mise EUMM, které se zaměřuje na oblast stabilizace, normalizace a budování důvěry, je zřejmé, že mise dosáhla určité stabilizace, nastavení důvěry mezi aktéry, ale stala se také součástí problému. EUMM také v podstatě umožnila Ruské federaci oficializovat její př́tomnost a jednotky v regionech Abcházie a Jižní Osetie.

Keywords: Common Security and Defence Policy; Borderization; Abkhazia; South Ossetia.

Klíčová slova: Společní bezpečnostní a obranná politika; borderizace; Abcházie; Jižní Osetie. 


\section{INTRODUCTION}

Eastern Neighbourhood has been a priority area for the European Union and of particular concern for the Central and Eastern European countries. Successive enlargements have brought the EU closer to Eastern European countries, improving their security, stability and prosperity. It is becoming increasingly important in terms of the impact they have on the Union.

Compared to the other EU neighbours, Georgia is showing the highest enthusiasm in developing closer ties to the Union. It has long made clear its interest in joining the EU and, in comparison to other partners in the European Neighbourhood Policy, it made a significant progress in undertaking political and economic reforms. However, within its own territory Georgia is involved in frozen conflicts that are a great obstacle in its further integration process.

The situation in the two breakaway regions, Abkhazia and South Ossetia, remains blocked and frozen. This led some commentators including the former EU Civilian Operations Commander to suggest that the European Union and its civilian EU Monitoring Mission in Georgia may have contributed to this "frozenness". As the EU stands as a mediator among the parties, it could prevent the direct communication among them and thus stop the situation from improving. Some authors even state that the Mission's activities do not correspond to the real peace-making activity, but rather to the EU's policy to reduce Russia's influence on the post-Soviet space ${ }^{1}$. The enthusiasm of Members States to contribute to the EUMM has also cooled down since the time of its inception, with some questioning whether the mission should continue at all due to possible "burn out syndrome". Although the Ukrainian crisis in 2014 has changed this perspective in most European capitals it is however necessary to evaluate the EU's presence and its added value. Particularly when Russian foreign policy becomes more assertive and aggressive in Georgia's immediate neighbourhood. Furthermore, mission's mandate has been extended by the Members States until the end of 2020. Thus, the evaluation indicators will focus on the main tasks of the European Union, EU Monitoring Mission (EUMM) in particular - stabilisation and confidence building.

As a result of my analysis, it will become clear whether the $\mathrm{EU}$ is contributing to the stability and conflict resolution after 10 years of its existence or it is rather becoming part of the problem through its presence. The analysis will contribute to the knowledge base of the crisis management that rarely encompasses a conflict in a holistic manner. The civilian dimension of the EU crisis management is crucial for the current crisis management and peacebuilding and yet remains marginalized, while significantly higher attention has been devoted to the military operations. Academic and media community, thus, pays insufficient attention to the civilian missions, and the role of the EU in this area. In addition, this article will bring significant new perspective due to the authors'

1 Samutina, O. S.; Yumatov, K. V. 2014. THE EUROPEAN UNION, RUSSIA AND THE GEORGIA - ABKHAZIA CONFLICT (1992 - 2015). Kemerovo State University Bulletin. 2014, Issue 3, p298-304. 7p. 
former involvement in the CSDP area in the post-Lisbon period. This allowed for personal interviews with the External Action Service and the Mission personnel.

\section{COMMON SECURITY AND DEFENSE POLICY}

The EU has launched 35 CSDP (Common Security and Defense Policy) missions since 2003 , but very little is known about them. The information available from open sources is limited to the information provided by the Council through its website, and only in the last few years have external valuations begun to appear. Compared to the uncritical and complacent descriptions of official reports, independent evaluations coincide in pinpointing common deficiencies in the missions. Among others, they point to a lack of strategy in the mandates, their limited results when it comes to solving the underlying problems, the democratic deficit in their management, the difficulty in coordinating interventions, the difference in strategic cultures among member states and the lack of military planning capacity. ${ }^{2}$

Evaluations of the civilian missions are difficult as missions have goals they merge with development goals or as the EUMM they aim at an objective that clashes with a more complex problem, such as a geopolitical conflict. Furthermore, lack of open source information, limited knowledge base of the decision-making and internal struggles among different EU actors lead to the overall negative analysis of the civilian missions. This complex environment, however, needs to be properly explained and analysed in order to prevent a short-sighted vision of the Common Security and Defence Policy. It is important to stress that civilian missions are a unique tool that other international organisations have not developed to such an extent as the EU and thus, it is an essential niche of the European Union.

Drawing from the European Security Strategy (2003), civilian crisis management under ESDP/CSDP was presented as a key component of EU external policy. However, CSDP is not a stand-alone instrument. ${ }^{3}$ "The trilogy of peace, security and development, reinforced by the imperative of good governance, is a principle enunciated in various official documents, notably the EU Security Strategy, which states that the EU is a global

2 Felix, Arteaga. 2011. The Need for an Open System to evaluate EU CSDP Missions. Royal Institute Elcano. Strategic and International Studies (http://www.realinstitutoelcano.org/wps/portal/web/rielcano_ en/contenido?WCM_GLOBAL_CONTEXT=/elcano/elcano_in/zonas_in/defense+security/ ari104-2011). Accessed on 31/7/2019.

3 Martinelli, Marta 2008. "Implementing the ESDP in Africa: The Case of the Democratic Republic of Congo" in: MERLINGEN Michael and OSTRAUSKAITE Rasa (Eds). 2008. European Security and Defence Policy. An implementation perspective. Routledge Tailor and Francis Group. London and New York. 
actor and as such must be ready to take responsibility for international security and for a better world". 4

The new Global Strategy of the European Union from 2016 stresses a very important integrated approach to the conflict - the so-called comprehensive approach:

When violent conflicts erupt, our shared vital interests are threatened. The EU will engage in a practical and principled way in peacebuilding, and foster human security through an integrated approach. Implementing the 'comprehensive approach to conflicts and crises' through a coherent use of all policies at the EU's disposal is essential. But the meaning and scope of the 'comprehensive approach' will be expanded. The EU will act at all stages of the conflict cycle, acting promptly on prevention, responding responsibly and decisively to crises, investing in stabilisation, and avoiding premature disengagement when a new crisis erupts. The EU will act at different levels of governance: conflicts such as those in Syria and Libya have local, national, regional and global dimensions which must be addressed. Finally, none of these conflicts can be solved by us alone. Sustainable peace can only be achieved through comprehensive agreements rooted in broad, deep and durable regional and international partnerships, which the EU will foster and support. ${ }^{\mathbf{5}}$

The two dimensions of this approach - the internal interaction and communication among EU actors and their coordination with the other actors remains key for the conflict resolution and a good impact of EU actions. However, both are very difficult to accomplish in the conflict areas which lead to mix results of the EU civilian missions.

The EUMM has been the fastest deployed civilian mission of the EU following the EU-mediated Six Point Agreement, which ended the Russo-Georgian War in August 2008. The Six Point Agreement has been not yet fully implemented as Russia continually fails to comply in full with point 5 of the Agreement. In fact, it has acted contrary to it by increasing its military presence in Abkhazia and South Ossetia and establishing new military bases in both regions. In addition, on 30 April 2009 a treaty was signed in Moscow between Russia and the de facto territories, providing for Russian border troops to be stationed along the administrative border lines to Georgia (or the "the rest of Georgia"). Currently it is estimated that in both breakaway regions there are around 20000 troops (!) funded by the Russian federation (informal source from the Mission). Russia has thus

4 European Security Strategy (ESS) 2003. (https://www.consilium.europa.eu/en/documentspublications/publications/european-security-strategy-secure-europe-better-world/). Accessed on $31 / 7 / 2019$.

5 EU Global Strategy 2016. (https://eeas.europa.eu/topics/eu-global-strategy_en), Accessed on $31 / 7 / 2019$. 
done everything in its ability to entrench and legalise the division of Georgia and the definitive separation of the two regions from Tbilisi. ${ }^{6}$

\section{GEOPOLITICAL CONFLICT}

The 2008 crisis in Georgia is a manifestation of a deeply rooted conflict. Firstly, the Georgia conflict is geopolitical, reflecting in particular Russia's position on the international stage, reaction to the West's recognition of Kosovo in 2008, enlargement of NATO to the East, which Russia considers to be a breach of agreements made during the negotiation in 1990 on German reunification, and Russian misgivings in other areas such as the NATO missile shield. It is also reflecting the perceived risk of losing Russia's influence in Southern Caucasus, where it has strategic interest (the oil and gas pipelines from Azerbaijan and Central Asia) and proximity to the troublesome Northern Caucasus with Chechnya and the forgotten war in Dagestan. ${ }^{7}$

Russia's recognition of the independence of Abkhazia and South Ossetia after the 2008 war between Russia and Georgia has made it more difficult to find a solution to the Georgia conflict. Such solution would probably be easier to find if it was part of a broader geopolitical engagement with Russia. ${ }^{8}$

Secondly, the conflict between Georgia and the breakaway areas of Abkhazia (ABK) and South Ossetia (SO) and the respective perceptions of the populations should be viewed on the background of not only the war in 2008, but also the wars in 1991-2 between Georgia and SO and in 1992-3 between Georgia and ABK during which all sides committed human rights violations towards the civilian population, including ethnic cleansing that resulted in large numbers of internally displaced persons (IDPs). About 250 000 Georgians fled from ABK and SO to Georgia during those wars, after which there was no longer a population majority of Georgians in ABK. In comparison, the short conflict which was in 2008 resulted in 30000 IDPs from only SO to Georgia. The backlog of these conflicts - in particular in terms of the Georgia/South Ossetia/Abkhazia relationship has to be factored into the analysis. ${ }^{9}$

6 Halbach in Asseburg and Kempin (Eds) 2009. The EU as a Strategic Author in the realm of Security and Defence? A Systematic Assessment of ESDP Mission and Operations. SWP Research Paper, German Institute for International Security Affairs, Berlin, p115.

7 European External Action Service (EEAS) Analysis 2012. EU-Georgia Relations Facts and figures. (https:// eeas.europa.eu/sites/eeas/files/eap_factsheet_georgia_eng.pdf)

8 EEAS Analysis. 2012. EU-Georgia relations. Internal document. Unpublished.

9 EEAS Analysis 2012. EU-Georgia relations. Internal document. Unpublished. 


\section{NON-RECOGNITION BUT ENGAGEMENT POLICY AND LACK OF ACCESS TO THE BREAKAWAY REGIONS}

Another important difficulty in the resolution of the conflict is the engagement policy with the breakaway regions. Comprehensive engagement is very contrasted from the Georgian and Russian side. The engagement policy constitutes a problem for the EU as well.

The former Georgian government of Prime Minister Ivanishvilli has made several positive steps to improve its relations with Russia and its engagement with ABK and SO while maintaining Georgia's policy of Euro-Atlantic integration and non-recognition of $\mathrm{ABK}$ and SO.

Russian Foreign Minister Lavrov has in recent statements maintained that Russia will not change its policy of recognition of $A B K$ and $S O$, and there are no indications that $A B K$ and SO would give up their de facto independence. In addition, following the Ukrainian crisis there were proofs of closer official ties with the breakaway regions. Russia has signed with ABK and SO integration and cooperation agreements in 2014 and 2015 which provide more official support at the international arena.

Ukrainian crisis on the other hand reunited the EU towards helping Georgia and Member States are no longer disputing the purpose of the mission, its usefulness and raison d'etre. In addition, the most vocal critic - Germany - held OSCE chairmanship in 2016. This probably also led to smoothening of Germany's criticism of the EUMM. Furthermore, the Mission downsizing and optimalisation in 2015 has responded to the criticism of an "oversized mission".

"The EU developed its non-recognition and engagement policy toward the breakaway regions of $A B K$ and SO in December 2009. In this regard one of the most innovative aspects of the EU policy was this creative policy of both non-recognition and engagement". ${ }^{10}$ Creative policy however proved to be quite complicated. The EU struggled to define the parameters what engagement should be and too rather cautious approach both with Georgian government and the breakaway regions. Despite this, it is remarkable that in Abkhazia the EU has been able to provide significant resources to Civil Society, sometimes through non-governmental organisation or through COBERM (confidence-building mechanism project financed by the European Commission). ${ }^{11}$

Thus, there is no technical fix to the current situation in Georgia, and a technical tool, such as a monitoring mission cannot alone provide a solution to a longstanding problem

10 European Neighbourhood Policy Progress Report. 2011. Joint Staff Working Paper: Implementation of the European Neighbourhood Policy in 2010. Country report: Georgia, Brussels, 25/05/2011 SEC(2011) 649.

11 Evaluation of the EU's cooperation with Georgia 2007-2013, EC Report 2015. (https://ec.europa. eu/europeaid/sites/devco/files/strategic-evaluation-cooperation-ec-georgia-1342-mainreport-201505_en.pdf). Accessed 31/7/2019. 
with a fundamental geopolitical dimension and complicated relationship of all actors involved. EUMM is not conflict-resolution mission; it is solely a stabilisation mission that can achieve certain results but not miracles. Thus the analysis of the conflict lead to important answers to the research question - the EU and the EUMM cannot resolve conflict as such, they can merely contribute to the stabilisation and confidence building and the EU is the greatest and a highly efficient actor in the area (particularly through Incident Prevention and Response Mechanisms, hotline and the confidence building measures - see in the subsequent parts of the paper). The only factor that is still an obstacle in even a bigger success and higher sustainability of EU actions is the integrated approach of all EU actors.

\section{ANALYSIS}

The mission EUMM is the only international monitoring mission on the ground as other international organisations - OSCE and the UN - were forced to close their missions following the war in 2008 as the Russian federation vetoed both missions. Its main focus is on "stability throughout Georgia and the surrounding region"12, and secondly "in the short term, to the stabilization of the situation with a reduced risk of a resumption of hostilities, in full compliance with the Six Point Agreement and the subsequent implementation measures"13. Three main areas of the Mission are the stabilisation, normalisation and confidence building measures. These will also form part of the analysis of the Mission.

\section{1 Stabilisation}

The mission monitors, analyses and reports on the situation pertaining to the stabilisation process, centred on compliance with the Six Point Agreement and on the freedom of movement and actions by spoilers, as well as on violation of human rights and international humanitarian law. ${ }^{14}$

The main aim of the mission is to prevent an open conflict and decrease tensions between the parties. There are two tools that the mission has at its disposal in order

12 Council Joint Action 2008/736/CFSP of 15 September 2008 on the European Union Monitoring Mission in Georgia, EUMM Georgia (https://publications.europa.eu/en/publication-detail/-/ publication/Obabfe13-406a-4fa3-b3a9-3b7aaOfe5236/language-en). Accessed on 31/7/2019.

13 Council Joint Action 2008/736/CFSP of 15 September 2008 on the European Union Monitoring Mission in Georgia, EUMM Georgia (https://publications.europa.eu/en/publication-detail/-/ publication/0babfe13-406a-4fa3-b3a9-3b7aaOfe5236/language-en). Accessed on 31/7/2019.

14 EUMM Website. (https://eumm.eu). Accessed 31/7/2019. 
to achieve such aim, the Incident Prevention and Response Mechanism and a "hotline" telephone system.

The Incident Prevention and Response Mechanism was created in February 2009 as a result of the Geneva Discussions that followed the 2008 conflict in Georgia. They are co-facilitated by the OSCE and the European Union Monitoring Mission in Georgia and the participants are Georgian, Russian, Abkhazian and South Ossetian side respectively in separate IPRMs and the United Nations. The meetings are an opportunity to discuss, among other issues: the identification of potential risks, the follow-up of incidents and the exchange of information, as well as problems affecting the communities on a daily basis. $^{15}$

Attached to the Mechanism is a "hotline" telephone system working in both theatres. The hotline has proven very useful for participants to effectively establish a common understanding of events surrounding specific incidents and it has repeatedly helped to de-escalate arising tensions. ${ }^{16}$ Around 200 calls per month have been in recent years accomplished.

Both tools are now working extremely efficiently due to the growing confidence in the Mission. However, for example the IPRM in Abkhazia has not functioned for four years. In April 2012 the breakaway Abkhazia's foreign ministry accused the then head of EU Monitoring Mission in Georgia (EUMM), Andrzej Tyszkiewicz, of "disrespect" towards Sokhumi and declared him as "an undesirable person on the territory of Abkhazia" (persona non grata). In a statement on April 25 2012, the breakaway region's foreign ministry expressed "utmost bewilderment" over, as it put it, "confrontational position taken by Head of the EU Monitoring Mission in Georgia", accusing him of "attempts to politically blackmail the Abkhaz side." "Mr. Tyszkiewicz is ignoring our requests and appeals and is putting forth unacceptable demands to allow EUMM on the territory of Abkhazia,"17 the statement reads. In short, A. Tyszkiewicz inappropriately addressed the Abkhaz side's leadership in a non-diplomatic way.

The diplomatic incident led to the stall of the IPRM for Abkhazia, which was quite an obstacle to the confidence building co-facilitated by the EUMM and the OSCE. The EU was criticized for choosing a non-diplomat for a position of EUMM Head of Mission in such a sensitive area where choice of words in communication is at the top of importance list. These were some of the lessons learned for other selection processes.

15 OSCE Website on Ergneti IPRM 50th meeting completed today, OSCE and EUMM co-facilitators commend participants' continued engagement (https://www.osce.org/cio/126792). Accessed on 31/7/2019.

16 OSCE Website on EU Monitoring Mission and OSCE build trust and confidence along ceasefire line in Georgia. (https://eeas.europa.eu/delegations/georgia/37836/eu-monitoring-mission-andosce-build-trust-and-confidence-along-ceasefire-line-georgia_my). Accessed on 31/7/2019

17 "Sukhumi slams EUMM Head" in Civil Georgia Daily News Online, 25 April 2012. (http://www.civil.ge/ eng/article.php?id=24693). Accessed on 31/7/2019. 
In support of the former Head of Mission, it is, however, important to note that despite the EUMM mandate the Mission does not have an access to the breakaway regions, even ten years after its inception. EUMM is mandated to cover the whole territory of Georgia, within the country's internationally recognized borders, but the authorities in breakaway Abkhazia and South Ossetia, as well as Russia, which has troops in those regions, deny access to EUMM to these territories under their control. This aspect can lead to frustration of the Mission leadership.

The reaction of the Abkhaz side led also to the mistrust of the Mission and the EU as a whole. "The EUMM under the leadership of Tyszkiewicz is clearly not disposed to carry out unbiased monitoring and to give an objective assessment to processes posing threat to security," it said. "In particular, Mr. Tyszkiewicz left without due attention process of establishing illegal armed groups on the Georgian territory adjacent to Abkhazia and South Ossetia about which number of Georgian politicians have reported."18

The Incident Prevention and Response Mechanism have been thus non-functional for four long years and it was reinvigorated only after a fatal incident at the Abkhazian boundary line. The fatal incident took place on 19 May at the Khurcha-Nabakevi crossing point on the Administrative Boundary Line. According to assessment based on local witnesses, armed security actors from the Abkhaz side of the bridge crossed over to Tbilisi Administered Territory (TAT) and carried out the shooting. EUMM has immediately activated the Hotline and facilitated the exchange of information.

The resumption of the IPRM has been also due to very capable leadership of Head of Mission Kestutis Jankauskas and his deputy who insisted on unbiased and neutral stance toward all interlocutors. However, even his leadership and the current Head of Mission (HoM) Erik Høeg is not successful enough to achieve access to the breakaway regions. As the HoM underlines on a regular basis, it would benefit everybody by providing an impartial and factual picture on many issues. ${ }^{19}$

The EUMM through the IPRMs and hotline provides great help in local solution to local problems, such as detentions, allowing access of children to schools and providing support to agriculture farmers (i.e. through financing projects on irrigation system, access to other side of Administrative Boundary Line, etc.)

In the last couple of years the EUMM has recently noted with concern an increase of detentions near the South Ossetian Administrative Boundary Line (ABL). In this context, the Mission has facilitated dialogue over the Hotline and appreciated the subsequent

18 "Sukhumi slams EUMM Head" in Civil Georgia Daily News Online, 25 April 2012. (http://www.civil.ge/ eng/article.php?id=24693). Accessed on 31/7/2019.

19 Please see EUMM Press Releases on the following website: (https://eumm.eu/en/press_and_public_ information/press_releases/?year=2019). Accessed on 30/6/2019. 
release of detainees from Tskhinvali. The exchange of detainees and prisoners between the Georgian side and the breakaway regions in the past year has also been a great success of EUMM mediation efforts. Another considerable success of IPRM is securing the safety for those conducting agricultural works in fields close to the ABL.

The EUMM continues to encourage the sides to explore the possibilities of finding "local solutions to local problems". This, however, must be pursed in a sensitive manner, as any agreement between the sides can be easily politicised (as seen in the above mentioned incident between the Head of Mission and the Abkhaz side).

The nature of $A B L$ has been in certain areas a problem of its own as it leads to the fact that certain parts of land are accessible only by crossing the ABL. Restricting freedom of movement directly affects the livelihood of the local population, an issue the Mission continues to monitor closely within its mandate. It is also a standing topic at the monthly Incident Prevention and Response Mechanism (IPRM) meetings, both Gali and Ergneti.

\section{2 Normalisation and Borderisation}

In this context, "borderisation" activities, i.e. building fences on the Administrative Boundary Lines (ABLs), from the side breakaway regions with a great support by the Russian federation are highly discussed at the IPRMs. On one hand, "borderisation" is criticized by the Georgian government as it goes against the status quo. Boundary lines slowly become borders and the entities are clearly more and more disconnected from the territory of Georgia. They also become a major obstacle for cross ABL confidence building measures.

"Borderisation" activities along both ABLs have had an adverse impact on dialogue efforts, people-to people contact and have further entrenched positions. They have also affected the IPRM process as SO participants refuse to discuss the issue point blank. The Georgian opposition has employed rhetoric around the erection of fences to undermine the Government of Georgia's new engagement initiatives. While it remains essential that the EU encourages Georgia to pursue a proactive policy towards the breakaway regions, EU must equally engage and press on the RF to refrain from spoiling actions. ${ }^{20}$

On the other hand, local population praises the borderisation efforts as it prevents them from crossing the $A B L$ by accident. The South Ossetian $A B L$ is currently fenced completely with few exceptions. The ABL with Abkhazia has still work to be done. It is also noted that $S O A B L$ has been done in much more professional way with clearly more financial help from the Russian Federation than the Abkhazian ABL. Ukrainian crises has also speeded up the "borderisation" efforts in Abkhazia and in the last months since the

20 EEAS Archive. EU Monitoring Mission analysis on „borderisation“. Internal document. Unpublished. 
beginning of 2015 the length of fence has allegedly tripled and a barb wire was installed. 21 In addition, demarcation lines have not been agreed by both sides. In many cases, families, villages and communities were divided by this borderisation actions and they were deprived of their land and relatives.

Another aspect that is connected to borderisation is the language issue. The rights of ethnic Georgians in both ABK and SO have come gradually under increasing pressure in the educational sphere. "Restrictions on teaching of ethnic GEO students in areas predominantly inhabited by ethnic Georgians continued. By September 2017, grades 1 to 6 in all schools were being taught in Russian." 22 At the same time, commuting across the boundary lines for educational purposes became increasingly difficult since the closure of the three controlled crossing points has been accomplished. In Abkhazia, around 100.000 people (almost half of the population) speak Georgian but since 2007, access to education in Georgian has been under severe restraint. The Abkhaz government is trying hard to promote the Abkhaz language, however, there are not enough qualified teachers that could deliver the instruction. Thus, the assertive action of the government led paradoxically to the promotion of Russian and not of the Abkhaz language.

In 2007, the de facto Abkhaz government adopted the Law on State Language in Abkhazia, in order to promote the Abkhaz language. Article 2 of the law states that Abkhaz is the only state language in Abkhazia, and Russian (alongside with Abkhaz) will be used in governmental institutions and official matters. It also states that "all citizens of the Republic of Abkhazia must command the state language" (i.e. Abkhaz). Following a language policy plan in line with the new legislation, the head of the administration in the Gali district, Temur Nadaraya, announced in March 2015 that all twenty schools in the lower Gali district would switch to a Russian-taught system, thus relegating Georgian to a single subject: "Georgian language and literature"... However, there are no qualified teachers in the region and those from other regions do not want to teach in Gali. The result of this is that at present, not a single school in the Lower Gali district offers education in Abkhaz, nor of Abkhaz. Instead, teaching is occurring in Russian, and Georgian has been relegated to a module only. It seems that the only winner in this language battle is the Russian language. ${ }^{23}$

21 Personal interview with a EUMM Mission representative (anonymous). Dated 7/8/2017. Interviewed by the author of this paper.

22 EEAS Archive. 2018. EU Monitoring Mission analysis on „borderisation“. Internal document. Unpublished.

23 The Gali district is inhabited mostly by Mingrelians, a subdivision within the Georgian ethnic group. Their language, Mingrelian, is very close to Georgian, although it has no written standard. As a result, Mingrelians use Georgian when writing (also since they were educated in Georgian in the Soviet period). Sandra Veloy Mateu. 2016. Language policy in Abkhazia: promoting Abkhazian or forgetting Georgian? In Nationalia 16/9/2016 (Accessed on 20/10/2019). 
The same is happening in South Ossetia, where Ossetian is slowly dying out. Most schools offer only Russian education as de facto laws modelled the ABK template and replace Georgian with Russian as the language of instruction.

In South Ossetia, access to mother tongue education for the ethnic Georgian population living in Akhalgori district ... came under threat from September 2017. De facto laws modelled on the ABK template replaced Georgian with Russian as the language of instruction from grade 1-4 with immediate effect. This deprived children of the right to education in mother tongue, but also seriously damaged the quality of education as the reforms were ill prepared and apparently poorly implemented. ${ }^{24}$

Thus, "normalisation" efforts of the European Union have not been materialised. Instead, the livelihood of the population has become much more restraint, not only in terms of freedom of movement but also in terms of human rights, i.e. in particular the right to education in your mother tongue. And EUMM has not been capable of stopping such deprivation in any way.

\section{3 Confidence building measures}

The third evaluation aspect is connected to the confidence building. It has been together with normalisation and stabilisation, the third main target of the EUMM. The European Union contributes to the confidence building among all parties. There are however significant challenges and difficulties.

Confidence building have focused on security matters identifying and addressing sources of tension, improving human security on the ground and exploring various possible security arrangements. European Union focuses on CBM not only within the CSDP realm but also in broader terms, by the EU Special Representative (EUSR) and EU Delegation (project COBERM). This causes a complication on its own as multiplicity of actors with different mandates is not very helpful in building confidence with local interlocutors. Particularly Internally Displaced Persons get frustrated in seeing regularly EUMM members to oversee their situation but with no direct influence in improving their situation. EUSR is promoting the CBMs within the General International Discussions in close cooperation with the UN and OSCE. The EUMM plays a key role, within the IPRM framework and its hotlines (mentioned above), as well as through its monitoring and reporting activities. Other aspects of CBMs have focused on the re-establishment of contacts and building of pragmatic relationships between communities and civil society actors across the ABL. Many efforts have been made outside of the formal negotiation frameworks, including as part of the EU's Non Recognition and Engagement Policy. The EU Delegation

24 EEAS Archive. 2018. EU Monitoring Mission analysis on „borderisation“. Internal document. Unpublished. 
to Georgia which works closely with international and local organisations operating on the ground, plays a key role in supporting such CBMs.

The Georgian-Abkhaz and Georgian-Ossetian conflicts in the early 1990s and the August 2008 conflict erupted not primarily due to inter-ethnic disputes but resulted from disagreements on the issue of status. These disagreements persist, but - for various reasons - have been excluded from the mandate of the Geneva International Discussion. Thus, not even these talks include the grassroots of the conflict. How can they then achieve the progress in the conflict resolution?

The current situation has limitations regarding the development of Confidence Building Measures (CBMs) as they essentially depend on the political will of the participants. Currently, the main obstacles to launching CBMs are the various obstacles and restrictions to access, including humanitarian access, combined with political conditions set by the entities. Also, the RF has no intention in allowing CBMs between Tbilisi and the entities or between the entities and the international community.

Another complicating parameter is the strong perception by the entities and the RF that the EU, US, UN, OSCE pursue their fundamental political agenda or re-integration of the entities into Georgia. Therefore, it is necessary to foster confidence in the EU's role as a fair mediator and observer and to re-build trust between the entities and the international community.

Furthermore, the on-going conflict in Ukraine had enormous impact on the Government of Georgia which tends to shift the problematic of the conflict to the broader geopolitical context of the foreign policy of Russia rather than to engage in the Geneva International Discussions (GID) and Incident Prevention and Response Mechanisms (IPRM) over Confidence Building Measures (CBM).

The EUMM can be also considered a CBM in itself as the main instrument for confidence building between security actors is the above mentioned IPRM, a mechanism to exchange information on security matters to discuss their implications for the local population. The most tangible results of IPRM meetings are the release of detainees, a lenient approach by RF border guards for Administrative Boundary Line (ABL) residents, and securing the safety for those conducting agricultural works in fields close to the ABL. The IPRMs are closely linked to the Geneva International Discussions where the EUMM participates as an observer and contributes with an update on the security situation on the ground. ${ }^{25}$

25 EEAS Archive. 2014. Internal document on Confidence building measures. Unpublished document. 


\section{COMPREHENSIVE APPROACH}

Over the years of engagement, each EU actor - EU Delegation, the EU Special Representative and the EUMM - has revealed their strengths and limitations. The EUSR works towards facilitating a wide spectrum of local and regional CBMs with political actors and civil society, identifying and generating new opportunities to inform and target the Non-Recognition and Engagement policy, to complement and enhance efforts of the GID co-chairs, and synergise efforts with other International Community actors. The EUMM's reporting, situational awareness and assessments informs other EU actors and CBMs proposed by the EUMM at the IPRM meeting are supported by the EU Special Representative's diplomatic endeavours. The EU Delegation plays the key role in programming and implementing CBM (within its development efforts) related to EU assistance in the overarching context of the EU's programmes for Georgia. The EUMM in line with is mandate could monitor CBM implementation, when appropriate, but cannot replace the European Commission's legal obligations and responsibilities. Thus, linkage between EUMM reporting and European Delegation project (that are funded through various instruments) is hardly sufficient.

Therefore, the EU needs to align existing policies and involved actors more closely with these goals. In parallel, it needs to consider ways to improve their coherence, so as to maximise its overall impact. The entry into force of the Treaty of Lisbon provides a timely opportunity to increase the efficiency and the coherence of the EU engagement. Closer and more effective coordination among all EU relevant actors, and with Members States, is essential.

The comprehensive approach should aim to integrate the civilian and military mission as the core of EU policies. It should "suggest mechanisms to bring together the relevant stakeholders at crucial points during the planning phase and lifespan of a mission to address issues of alignment, complementarity and sequencing of the various instruments, which can be implemented within the current structures, with full respect for the various competencies and with the necessary flexibility bearing in mind the needs of crisis management. It seeks to do this without cumbersome new procedures, creating new layers in the decision-making processes or new potential obstacles that could slow down swift CSDP action in case of urgency. In fact, applying these mechanisms will save significant time and effort during the deployment and mandate delivery of CSDP missions." 26

26 Non-Paper of numerous Member States on Comprehensive Approach. 30/4/2014. Informal document. 


\section{CONCLUSION}

Following the analysis of the three key aspects of the EU Monitoring Mission it is clear that there are some improvements, but overall situation has worsened. Georgia and its territorial integrity has been seriously violated by Russian presence and rights of Georgians in the breakaway regions are very limited. Children are deprived of the right to be taught in their mother tongue. Border lines are drawn where people had their property rights and where they used to farm. Following the decade since the conflict in 2008 erupted there has been stabilisation established but at the detriment of the people concerned. EUMM is an important factor in stabilisation and confidence building activities, however its presence does not prevent the Russian federation from spreading its sphere of influence. As it was stated, the EUMM and the presence of more than 300 monitors give the EU insight on what is at stake in the region. It is a technical tool that does not have the ambition to resolve the conflict. It is there to increase the confidence building, to mediate among the actors in order to achieve a normal and a stable environment. But on the other hand, EUMM enables also the Russian federation to officialise its presence and its troops in the breakaway regions. This could have serious consequences on its future role as an important player in international relations. The EU should activate all instruments that it has at its disposal to make a progress. Otherwise, it risks that it would contribute to the deadlock. The EU as superpower has the possibilities to de-freeze the conflict and make itself a credible partner to Georgia, its most faithful ally in the region.

Author: $\quad$ PhDr. Tereza Smejkalová, Ph.D., born in 1979. She has studied at the Charles University, Institute of Political Science in Strasbourg, Queensland University in Australia and Diplomatic Academy in Vienna. She has worked as a diplomat in Vienna and Brussels, now she is a Chair of Political Science at Anglo-American University in Prague. She focuses on European affairs, in particular, security matters. She has published several articles in Czech and foreign periodicals.

How to cite:SMEJKALOVÁ Tereza. European Union Monitoring Mission in Georgia (20082019): contribution to stability or part of a problem? Vojenské rozhledy. 2019, 28 (4), 003-017. ISSN 1210-3292 (print), 2336-2995 (on-line). Available at: www.vojenskerozhledy.cz 